\title{
Clinical Application of Dose Reconstruction Based on Full-Scope Monte Carlo Calculations: Composite Dose Reconstruction on a Deformed Phantom
}

\author{
Inhwan Yeo*, Qianyi $\mathrm{Xu}^{\dagger}$, Yan $\mathrm{Chen}^{\dagger}$, Jae Won Jung ${ }^{\ddagger}$, Jong Oh $\mathrm{Kim}^{\S}$ \\ *Loma Linda University Medical Center, Loma Linda, CA, ${ }^{\dagger}$ Cooper University Hospital, Camden, NJ, \\ ${ }^{\ddagger}$ East Carolina University, Greenville, NC, ${ }^{\S}$ University of Pittsburgh Cancer Institute, Pittsburgh, PA, USA
}

The purpose of this study was to develop a system of clinical application of reconstructed dose that includes dose reconstruction, reconstructed dose registration between fractions of treatment, and dose-volume-histogram generation and to demonstrate the system on a deformable prostate phantom. To achieve this purpose, a deformable prostate phantom was embedded into a $20 \mathrm{~cm}$-deep and $40 \mathrm{~cm}$-wide water phantom. The phantom was CT scanned and the anatomical models of prostate, seminal vesicles, and rectum were contoured. A coplanar 4-field intensity modulated radiation therapy (IMRT) plan was used for this study. Organ deformation was simulated by inserting a "transrectal" balloon containing $20 \mathrm{ml}$ of water. A new CT scan was obtained and the deformed structures were contoured. Dose responses in phantoms and electronic portal imaging device (EPID) were calculated by using the XVMC Monte Carlo code. The IMRT plan was delivered to the two phantoms and integrated EPID images were respectively acquired. Dose reconstruction was performed on these images using the calculated responses. The deformed phantom was registered to the original phantom using an in-house developed software based on the Demons algorithm. The transfer matrix for each voxel was obtained and used to correlate the two sets of the reconstructed dose to generate a cumulative reconstructed dose on the original phantom. Forwardly calculated planning dose in the original phantom was compared to the cumulative reconstructed dose from EPID in the original phantom. The prescribed 200 cGy isodose lines showed little difference with respect to the "prostate" and "seminal vesicles", but appreciable difference (3\%) was observed at the dose level greater than 210 cGy. In the rectum, the reconstructed dose showed lower volume coverage by a few percent than the plan dose in the dose range of 150 to 200 cGy. Through this study, the system of clinical application of reconstructed dose was successfully developed and demonstrated. The organ deformation simulated in this study resulted in small but observable dose changes in the target and critical structure.

Key Words: Dose reconstruction, Deformation

\section{Introduction}

Dose reconstruction, by providing an entire dose distribution delivered in a patient anatomy, verifies radiation delivery in a

Jong Kim acknowledges the support of Dr. Fippel in allowing him to use the XVMC code. This study was in part supported by Varian Medical Systems, Inc.

Received 25 August 2014, Revised 30 August 2014, Accepted 6 September 2014

Correspondence: Inhwan Yeo (medicphys@hotmail.com) Tel: 1-909-558-4904, Fax: 1-909-558-4083

(C) This is an Open-Access article distributed under the terms of the Creative Commons Attribution Non-Commercial License (http://creativecommons.org/licenses/by-nc/3.0) which permits unrestricted non-commercial use, distribution, and reproduction in any medium, provided the original work is properly cited. clinically meaningful way. ${ }^{1-7)}$ It assumes that the anatomical information (i.e. computer tomography or CT) of a patient under treatment is available and reconstructs "delivered" dose to such information from "transit" dose recorded in EPID.

In reality, the anatomical information varies between the time of pretreatment CT for treatment planning and the time of radiation delivery for treatment. This variation is repeated between fractions of treatment. To evaluate the reconstructed dose clinically, this variation has to be considered. This can be done by reconstructing dose and adding the dose over fractions of treatment via registration, representing the cumulative dose in a pretreatment CT image, and comparatively evaluating it with the planned dose. 
In our prior study, we have developed and successfully demonstrated a method of dose reconstruction. ${ }^{2-4)}$ In this study, our objectives are (1) to develop a system of clinical application of reconstructed dose (above mentioned) that includes dose registration between fractions of treatment and dose-volume-histogram generation and (2) to demonstrate it on a deformable prostate phantom.

\section{Materials and Methods}

Procedures of experiments and computations in this study are shown in Fig. 1. We have devised a deformable phantom by placing an ultrasound training phantom (Model 053, Computerized imaging reference systems, Inc., Norfolk, VA, US) into a $20 \mathrm{~cm}$-deep and $40 \mathrm{~cm}$-wide water phantom. We have imaged the phantom, contoured the "prostate", "seminal vesicles" (SV), and "rectum", and generated an intensity- modulated plan using a pair of opposed fields. The planning was performed in a XIO system (Elekta, Inc., Atlanta, GA, US) using the prescription dose of $200 \mathrm{cGy}$ to the prostate planning

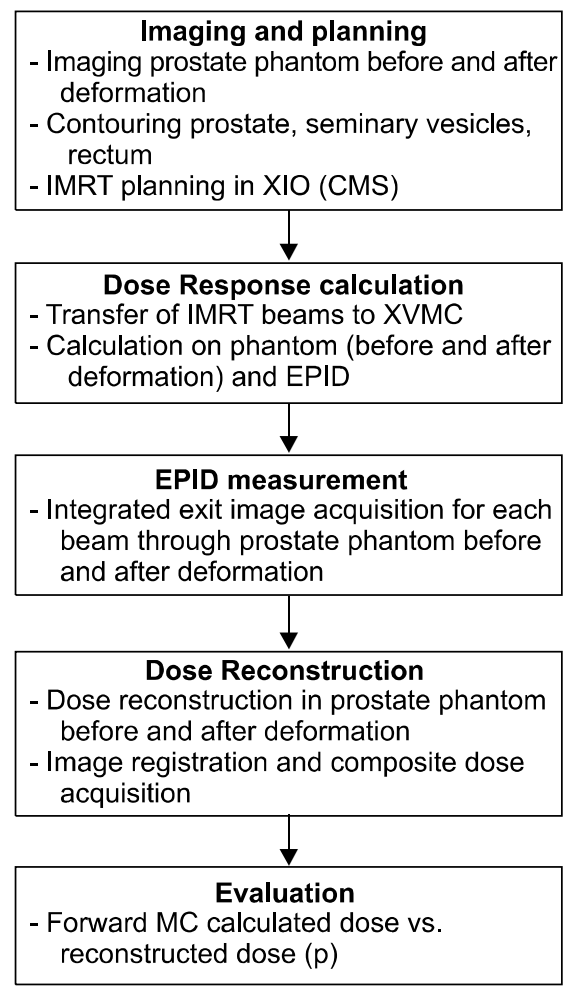

Fig. 1. Study procedures. target volume (PTV). PTV margins were $0.5 \mathrm{~cm}$ for both prostate and SV. The optimized beams were transferred to the XVMC Monte Carlo (MC) $\operatorname{code}^{8)}$ for the calculation of dose responses in the phantom and EPID for dose reconstruction. The calculated responses for each IMRT beam are later used for dose reconstruction. Details of the computational process for the response calculations and dose reconstruction are provided in our prior work. ${ }^{2-4)}$

We have simulated a clinical situation that involves internal organ motion during treatment while treatment planning is done by the initial set of the CT scans. We have created a second set of CT images for the phantom being deformed by inserting a "transrectal" balloon containing $20 \mathrm{ml}$ of water. The "prostate" and "SV" were pressed and thus were deformed by the expansion of the balloon. The deformed phantom is meant to mimic an internal anatomy change of a patient at a treatment session with respect to the anatomy at the CT simulation. The contouring of prostate, SV, and rectum was done on this deformed phantom. The calculation of dose responses was repeated for the deformed phantom.

The IMRT beams were irradiated to both sets of the phantom and an integrated image in EPID were acquired for each beam. Dose reconstruction was performed using these images and the above-calculated responses. The image set after deformation was deformably registered to the image set before deformation using our internally-developed software based on the Demons algorithm. ${ }^{9}$ ) The transfer matrix for each image voxel was obtained and used to correlate the two sets of the reconstructed dose generating a cumulative reconstructed dose for each organ on the first image set (planning CT images).

From the cumulative dose, a dose volume histogram for each organ was generated using an in-house algorithm that were developed to utilize the coordinate information of each organ contour and the dose matrix within each contour, calculating cumulative dose volume data.

\section{Results}

Using the calculated responses, we have obtained forwardly calculated dose (MC) in the phantom before deformation (Plan), inversely reconstructed dose in the phantom before deformation (Reconstruction 1), and inversely reconstructed dose 


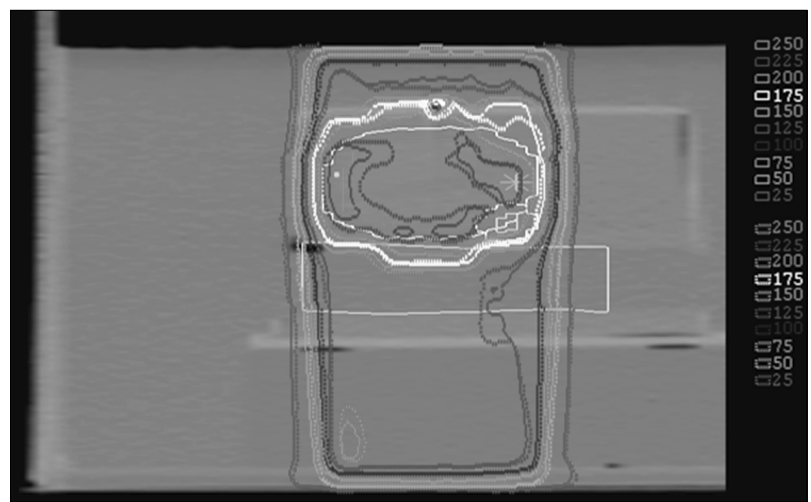

Fig. 2. Isodose comparison between plan (solid) and reconstruc tion (dashed) on the isocentric sagittal plane. Various isodose lines (legends on the righthand side) are plotted. The prostate is contoured in red color; the prostate PTV in white color; the SV PTV in green color; the rectum in cyan color.

in the phantom after deformation (Reconstruction 2). The deformable registration took approximately 2 minutes on a MacBook Pro laptop with two $2.4 \mathrm{GHz}$ Intel CPUs and $4 \mathrm{~GB}$ memory. From the two sets of the reconstructed doses, a cumulative dose was determined on the first set of the phantom image. Figure 2 compares the plan with the cumulative reconstructed dose in an isocentric sagittal slice that shows the prostate, SV, and rectum. Figure 3 similarly compares in an isocentric axial slice. Figure 4 compares the plan with the cumulative reconstruction in dose volume histogram for each organ. The figure shows amounts of deviation between the plan and the delivery for the prostate PTV, SV PTV, and the rectum. We observed no difference between the plan and the delivery for the PTVs at 200 cGy (prescription dose), but appreciable differences at a higher dose region that include 3\% greater volume coverage by the reconstructed dose at $\sim 210$ cGy for the prostate PTV and somewhat lower volume coverage by the reconstructed dose in the region of dose volume gradient for the SV PTV. In the rectum, the reconstructed dose showed lower volume coverage by a few percent than the plan dose in the dose range of 150 to 200 cGy.

\section{Conclusions}

The dose reconstruction we have developed has been further applied on a deformed organ in this study through the devel-

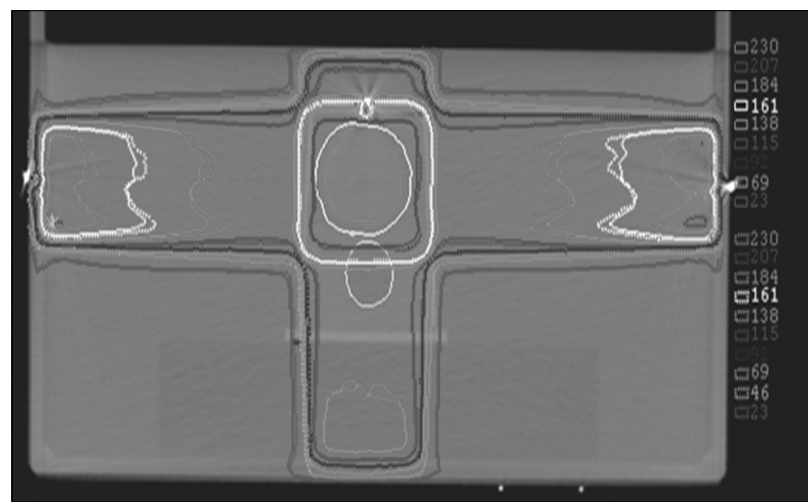

Fig. 3. Isodose comparison between plan (solid) and reconstruction (dashed) on the isocentric axial plane. Various isodose lines (legends on the righthand side) are plotted.

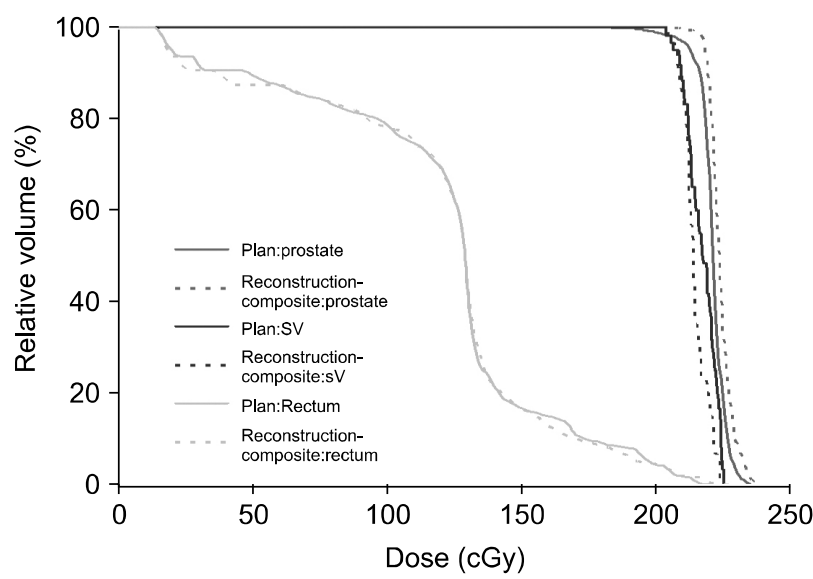

Fig. 4. Dose-volume-histogram comparison between plan (solid) and reconstruction (dashed).

opment of a clinical framework of dose reconstruction. The framework included the deformable registration of reconstructed doses and the dose volume histogram generation. The framework was useful to validate dose three dimensionally in a clinically meaningful way. The organ deformation simulated in this study resulted in small but observable dose changes in the target and critical structure. When irradiating internal organs that deform as a part of radiation therapy, this framework can be used to determine the amount of difference between the plan and the delivery that needs clinical consideration. This can then be taken as input data for adaptive planning for further and remaining dose delivery. 


\section{References}

1. Mijnheer B, Beddar S, Izewska J, Reft C: In vivo dosimetry in external beam radiotherapy. Med Phy 40(7):070903 (2013)

2. Yeo IJ, Jung JW, Yi BY, Kim JO: Feasibility study on inverse four-dimensional dose reconstruction using the continuous doseimage of EPID. Med Phys 40(5):051702 (2013)

3. Yeo IJ, Jung JW, Chew M, et al: Dose reconstruction for intensity-modulated radiation therapy using a non-iterative method and portal dose image. Phys Med Biol 54(17):5223-36 (2009)

4. Jung JW, Kim JO, Yeo IJ, et al: Fast transit portal dosimetry using density-scaled layer modeling of aSi-based electronic portal imaging device and Monte Carlo method. Med Phys 39(12):
7593-602 (2012)

5. Elmpt W van, Nijsten S, Petit S, et al: $3 D$ in vivo dosimetry using megavoltage cone-beam CT and EPID dosimetry. Int $\mathrm{J}$ Radiat Oncol Biol Phys 73(5):1580-7 (2009)

6. Spezi E, Lewis DG: Full forward Monte Carlo calculation of portal dose from MLC collimated treatment beams. Phys Med Biol 47(3):377-90 (2002)

7. Partridge $M$, Ebert $M$, Hesse $B-M$ : IMRT verification by three-dimensional dose reconstruction from portal beam measurements. Med Phy 29(8):1847 (2002)

8. Fippel M: Fast Monte Carlo dose calculation for photon beams based on the VMC electron algorithm. Med Phys 26(8):1466-75 (1999)

9. Thirion JP: Image matching as a diffusion process: an analogy with Maxwell's demons 2(3):243-260(2004)

\section{몬테칼로 계산을 통한 흡수선량 재구성의 임상적 응용: 변형된 팬텀에서의 총제적 선량재구성}

*Loma Linda University Medical Center, Loma Linda, CA, ${ }^{\dagger}$ Cooper University Hospital, Camden, NJ,

${ }^{\ddagger}$ East Carolina University, Greenville, NC, ${ }^{\S}$ University of Pittsburgh Cancer Institute, Pittsburgh, PA, USA

Inhwan $\mathrm{Yeo}^{*}$, Qianyi $\mathrm{Xu}^{\dagger}$, Yan $\mathrm{Chen}^{\dagger}$, Jae Won Jung ${ }^{\dagger}$, Jong Oh $\mathrm{Kim}^{\S}$

본 연구의 목적은 흡수선량 재구성, 방사선 치료간의 재구성된 선량의 등록, 선량-체적 히스토그램의 생산등을 수행하는 선량 재구성의 임상적 응용시스템을 만들고 그것을 변형된 전립선 팬텀에 적용하는 것이다. 이를 위해 변형가능한 전립 선 팬텀을 $20 \mathrm{~cm}$ 깊이와 $40 \mathrm{~cm}$ 너비의 물팬텀에 집에 넣었다. 이것의 영상을 얻고, 전립선, 정낭 및 항문의 윤곽을 그렸 다. 동일 평면에서 네개의 조사문을 이용하여 세기 변조계획을 세웠다.항문에 $20 \mathrm{ml}$ 의 물풍선을 삽입하여 장기를 변형시 켰다. 영상을 다시 획득하여 위 장기의 윤곽을 그렸다. XVMC몬테칼로 코드를 사용하여 두 팬텀및 $\mathrm{EPID}$ 내에서 선량반응 인자를 계산하였다. 세기변조계획에서 얻어진 방사선을 두팬텀에 조사하여 EPID에서 적분형 영상을 얻었다. Demons 방 법을 사용하여 변형된 팬텀을 변형전 팬텀에 등록시켰다. 이를 통해 단위체적별 위치변이 정보를 얻었고 이를 이용해 두 팬텀의 재 구성된 선량을 합하여 변형전 팬텀에 생산해 냈다. 순방향으로 계산된 치료계획 선량을 합산된 재구성된 선량과 비교하였다. $200 \mathrm{cGy}$ 에서 전립선과 정낭이 받든 체적은 차이를 거의 보이지 않았으나, $210 \mathrm{cGy}$ 이상에서는 $3 \%$ 가 량 차이를 보였다. 항문에서는 150-200 cGy영역에서 재구성된 선량에 의하여 받은 체적은 치료 계획과 비교하여 3\% 이 상 적었다. 본 연구를 통하여 선량 재구성의 임상적 응용시스템이 성공적으로 만들어 젔다. 변형된 전립선 팬텀에 적용 되어 작지 않은 선량의 차이를 목표장기와 보호 장기에 보였다.

중심단어: 선량 재구성, 팬텀변형 